Journal An-Nafs: Kajian Penelitian Psikologi

http://ejournal.iai-tribakti.ac.id/index.php/psikologi

e-ISSN: 2549-6166

p-ISSN: 2528-0600

\title{
SENSE OF COMMUNITY DAN SELF-REGULATED LEARNING SEBAGAI PREDIKTOR PADA PROKRASTINASI AKADEMIK MAHASISWA UNIVERSITAS MUHAMMADIYAH SIDOARJO
}

\author{
Effy Wardati Maryam ${ }^{1}$, Ghozali Rusyid Affandi ${ }^{2}$ \& Vanda Rezania ${ }^{3}$ \\ 1effywardati@umsida.ac.id, 22ghozali@umsida.ac.id \& \\ 33vanda1@umsida.ac.id \\ Universitas Muhammadiyah Sidoarjo \\ https://doi.org/10.33367/psi.v4i2.867
}

\begin{abstract}
Abstrak
Prokrastinasi akademik pada mahasiswa menjadi faktor penentu keberhasilan mahasiswa dalam menyelesaikan studinya. Keterikatan dengan komunitas dan kemampuan mahasiswa untuk mengatur dirinya dalam belajar turut berperan dalam prokrastinasi akademik. Penelitian ini bertujuan untuk mengetahui keterkaitan Sense of Community (SoC) dan Self Regulated Learning (SRL) dengan Prokrastinasi Akademik. Populasi penelitian ini adalah seluruh mahasiswa UMSIDA semester ganjil tahun akademik 2018-2019 sebanyak 9824 mahasiswa dan total sampel berdasarkan tabel Isaac dan Michael dengan taraf kesalahan sebesar 5\% yaitu sebanyak 385 mahasiswa dengan teknik sampling proportioned random sampling. Pengumpulan data penelitian menggunakan tiga skala psikologis, yaitu skala prokrastinasi akademik, skala sense of community, dan skala self regulated learning. Analisis data penelitian menggunakan korelasi product moment dan analisis regresi ganda. Hasil analisa menunjukkan bahwa Sense of Community dan Self Regulated Learning memiliki hubungan negatif dengan prokrastinasi akademik. Apabila mahasiswa mempersepsikan dirinya memiliki Sense of Community dan Self Regulated Learning yang tinggi akan cenderung menurunkan prokrastinasi akademiknya. Namun daya prediksi Self Regulated Learning pada prokrastinasi akademik lebih tinggi dari pada Sense of Community pada prokrastinasi akademik.
\end{abstract}

Kata kunci: Sense of Community, Self Regulated Learning, Prokrastinasi Akademik

182-200 | Journal An-nafs: Vol. 4 No. 2 Desember 2019 
Effy Wardati M, Ghozali Rusyid A \& Vanda Rezania | Sense of

\begin{abstract}
Academic procrastination in students is a determining factor for the success of students in completing their studies. Engagement with the community and the ability of students to organize themselves in learning also play a role in academic procrastination. This study aims to determine the relationship of Sense of Community (SoC) and Self Regulated Learning (SRL) with Academic Procrastination. The population of this study was all UMSIDA students in the odd semester of 2018-2019 academic year with the total number of 9824 students and the total sample based on Isaac and Michael's table with an 5\% error rate were 385 students with a proportioned random sampling technique. Research data collection used three psychological scales, namely the scale of academic procrastination, the scale of the sense of community, and the scale of self-regulated learning. Analysis of research data used was product moment correlation and multiple regression analysis. The results of the analysis show that the Sense of Community and Self-Regulated Learning have a negative relationship with academic procrastination. If students perceive themselves to have a Sense of Community and high Self-Regulated Learning, they will tend to reduce their academic procrastination. However, the Self-Regulated Learning prediction on academic procrastination is higher than the Sense of Community on academic procrastination.
\end{abstract}

\title{
Keyword: Sense of Community, Self-Regulated Learning, Academic Procrastination
}


Effy Wardati M, Ghozali Rusyid A \& Vanda Rezania | Sense of

\section{Pendahuluan}

Masa perkuliahan seringkali dianggap sebagai masa yang berat bagi seorang mahasiswa. Selama menjalani proses perkuliahan, mahasiswa selalu dihadapkan oleh tuntutan-tuntutan, keputusan-keputusan, dan pilihan yang perlu diambil. Akibat dari banyaknya tuntutan dan permasalahan tersebut menyebabkan mahasiswa sering terlambat dalam menyelesaikan tugas perkuliahan, mengerjakan tugas perkuliahan dengan Sistem Kebut Semalam atau biasa yang kita sebut dengan "SKS", terlambat masuk di jam perkuliahan, tidak mengikuti perkuliahan atau membolos, bahkan ada yang sempat menunda dalam menyelesaikan tugas akhir atau skripsi. Fenomena-fenomena seperti ini yang diistilahkan dengan perilaku penundaan atau biasa dikenal dengan istilah prokrastinasi akademik. Hal tersebut didasarkan atas aspekaspek prokrastinasi yang dikemukakan oleh Ferrari: 1) Penundaan untuk memulai maupun menyelesaikan tugas. 2) Keterlambatan menyelesaikan tugas. 3) Kesenjangan waktu antara rencana dan kinerja aktual. 4) Melakukan aktifitas yang lebih menyenangkan (Ghufron \& Risnawita, 2016). Steel dan Klingsieck mengatakan bahwa prokrastinasi akademik mengacu pada penundaan secara sengaja dari kegiatan yang diinginkan meskipun individu mengetahui bahwa perilaku penundaan tersebut menghasilkan dampak buruk (Goroshit, 2018). Prokrastinasi juga bisa menjadi sebuah kecenderungan yang kronis atas kebiasaan untuk menunda hal-hal yang harus dilakukan (van Eerde \& Klingsieck, 2018).

Terdapat dua bentuk prokrastinasi yaitu prokrastinasi aktif dan pasif yang berkenaan dengan. Prokratinasi aktif mengarah pada penundaan yang disengaja, sehingga memiliki motivasi yang kuat meskipun dibawah tekanan waktu, mereka dapat menyelesaikan tugas sebelum tengang waktu habis serta dapat mencapai hasil yang memuaskan. Berbeda dengan prokrastinasi pasif yang merupakan prokrastinasi dalam bentuk penunadaan sampai batas akhir disertai dengan perasaan bersalah dan tertekan serta cenderung agagal menyelesaikan tugas (Choi \& Moran, 2009).

184 | Journal An-nafs: Vol. 4 No. 2 Desember 2019 
Effy Wardati M, Ghozali Rusyid A \& Vanda Rezania | Sense of

Berdasarkan penelitian yang dilakukan oleh Steel diketahui bahwa berkisar antara 80\%-95\% mahasiswa melakukan prokrastinasi yang terdiri dari $75 \%$ menngemukakan bahwa prokrastinasi sudah menjadi kebiasaan dan sekitar 50\% mengemukakan bahwa perilaku prokrastinasi terjadi secara konsisten dan mengakibatkan berbagai masalah akademik (Steel, 2007). Sedangkan penelitian Onwuegbuzie menunjukkan bahwa hampir 40\%-60\% mahasiswa melakukan menunda-nunda untuk mengerjakan tugas menyusun makalah dan tugas memahami materi baik untuk Ujian Akhir Semester (UAS) maupun membaca materi yang telah atau akan diberikan (Onwuegbuzie, 2004).

Terdapat dua faktor yang mempengaruhi prokrastinasi yaitu faktor internal dan eksternal (Ghufron \& Risnawita, 2016). Faktor internal meliputi kondisi fisik individu dan psikologis dari individu seperti motivasi, kontrol diri, trait individu, kemampuan mengelola diri dan lain-lain. Sedangkan faktor ekstrenal meliputi model pengasuhan orang tua dan lingkungan yang kondusif, yaitu lingkungan yang lenient (Ghufron \& Risnawita, 2016).

Lingkungan akademik yang secara langsung berhubungan dengan mahasiswa adalah lingkungan perguruan tinggi. Menurut Berns, perguruan tinggi menyediakan sarana potensial bagi kegiatan pembelajaran dan anggotanya berkomitmen untuk mencapai tujuan yang berpengaruh positif bagi pertumbuhan dan perkembangan anggota (Purwantika, Setyawan, \& Ariati, 2013). Mahasiswa bisa belajar dan berprestasi secara optimal hanya jika merasa nyaman secara fisik dan psikologis di kampus (Ormrod, 2008). Perasaan aman dan nyaman, saling peduli, saling percaya, dan terdapat ikatan emosional antar anggota komunitas disebut dengan sense of community (Dalton, Elias, \& Wandersman, 2007). McMillan dan Chavis menjelaskan bahwa sense of community merupakan perasaan bahwa anggota komunitas memiliki keterikatan, sebuah perasaan bahwa anggota memiliki arti terhadap anggota lainnya dan terhadap anggota komunitas, serta adanya keyakinan bersama bahwa kebutuhan para anggota dapat dicapai melalui komitmen mereka untuk bersama (Maryam, 2017). 
Effy Wardati M, Ghozali Rusyid A \& Vanda Rezania | Sense of

Cheng mengatakan bahwa sense of community erat kaitannya dengan perasaan diperhatikan, diperlakukan dengan baik, dihargai sebagai seorang individu, serta diterima sebagai bagian dari komunitas dan kehidupan sosial di kampus oleh anggota lain (Purwantika dkk., 2013). Ormrod menyatakan bahwa sense of community sebagai perasaan memiliki tujuan bersama, saling menghargai, mendukung usaha satu sama lain, serta percaya bahwa setiap orang memberi kontribusi yang penting bagi anggota kelompok yang lain memiliki aspek-aspek antara lain: Sense of community memiliki empat aspek, meliputi: 1) Keanggotaan (membership), 2). Pengaruh (influence), 3) Integrasi dan pemenuhan kebutuhan (Integration and Fullfillment of Need), 4) Berbagi hubungan emosional (shared emotional connection) (Purwantika dkk., 2013). Menurut penelitian Purwantika, dkk. (2013) terdapat hubungan negatif yang signifikan antara sense of community dengan prokrastinasi akademik pada mahasiswa Fakultas Psikologi Universitas Diponegoro Semarang. Semakin tinggi sense of community maka semakin rendah prokrastinasi akademik, dan sebaliknya.

Selain faktor bagaimana seseorang merasa terikat dengan kelompoknya yang disebut dengan sense of community, faktor internal lainnya yang juga turut mempengaruhi dan bisa menjadi faktor yang akan mengurangi prokrastinasi akademik adalah kemampuan seseorang untuk mengatur dirinya dalam belajar yang disebut dengan Self-Regulated Learning. Self-Regulated Learning mengacu pada kemampuan siswa untuk memahami dan mengontrol dirinya dalam belajar yang didalamnya terdapat aspek cognitive, metakognitive, behavioral, motivational dan emotional (Panadero, 2017). Self-Regulated Learning merupakan proses aktif dimana peserta didik membangun tujuan untuk belajar. Menurut Garcia et al. (2015) Self-Regulated Learning diartikan sebagai prosedur yang diterapkan oleh individu yang berusaha untuk mencapai tujuan yang telah ditetapkan dan terdiri dari dua strategi yang saling terkait yaitu assessment dan locomotion. Sedangkan menurut Zimmerman (dalam Mulyadi et al., 2016), Self Regulated

186 | Journal An-nafs: Vol. 4 No. 2 Desember 2019 
Learning adalah kemampuan untuk melakukan pengecekan, merencanakan, memonitor, merevisi, mengetes, dan mengevaluasi dari aktivitas belajar. Aspek-aspek self regulated learning, terdiri dari : 1) Evaluasi diri, 2) Mengatur dan mengubah, 3) Menetapkan tujuan dan perencanaan, 4) Mencari informasi, 5) Menyimpan catatan dan memantau, 6) Mengatur lingkungan, 7) Konsekuensi diri, 8) Mengulang dan mengingat, 9) Mencari dukungan sosial, 10) Memeriksa catatan (Zimmerman \& Martinez-Pons, 1988). Menurut San, Roslan, \& Sabouripour (2016) bahwa aspek self-regulated learning terbagi menjadi dua aspek yaitu aspek motivasi dan strategi belajar. Aspek Motivation yang terdiri dari Nilai (orientasi instrinsik, orietnasi esktrinsik, nilai dari sebuah tugas), Harapan (kontrol keyakinan dalam belajar, efikasi diri dalam belajar dan kinerja, afektif (kecemasan). Aspek strategi belajar terdiri dari kognitif dan metakognitif (kemampuan mengulang materi, elaborasi, pengorganisaian dalam belajar, kemampuan berfikir kritis, metakognisi regulasi diri), strategi managemen kemampuan.

Siswa yang memiliki Self-Regulated Learning baik akan lebih mampu mengurangi perilaku prokrastinasi akademik dalam proses belajarnya. Sebagaimana penelitian terdahu menunjukkan bahwa siswa yang menganggap bahwa regulasi diri mereka buruk maka akan berdampak perilaku prokrastinasi yang tinggi, namun jika siswa tersebut memiliki Self-Regulated Learning (information processing) yang bagus akan berdampak pada perilaku prokrastinasi yang rendah (de Palo, Monacis, Miceli, Sinatra, \& Di Nuovo, 2017). Hasil studi dari Hu dan Driscoll menemukan bahwa Self-Regulated Learning sangat dibutuhkan pada proses pembelajaran yang memerlukan kemandirian besar sebagaimana pendidikan di perguruan tinggi (Mulyadi, Basuki, \& Rahardjo, 2016). Sehingga tujuan dari penelitian adalah untuk mengetahui keterkaitan antara sense of community dan Self-Regulated Learning dengan prokrastinasi akademik mahasiswa Universitas Muhammadiyah Sidoarjo (UMSIDA) dan untuk mengetahui berapa besar daya prediksi secara bersama-sama dan sendiri-sendiri sense 
Effy Wardati M, Ghozali Rusyid A \& Vanda Rezania | Sense of

of community dan Self-Regulated Learning pada prokrasinasi akademik mahasiswa UMSIDA.

\section{Metode Penelitian}

Tipe penelitian ini adalah kuantitatif korelasional. Adapun populasi penelitian ini adalah seluruh mahasiswa UMSIDA yang berada di semester ganjil tahun akademik 2018-2019 sebanyak 9824 mahasiswa. Jumlah sampel dalam penelitian didasarkan pada tabel Isaac dan Michael dengan taraf kesalahan sebesar 5\% yaitu sebanyak 385 mahasiswa (Sugiyono, 2011). Teknik sampling yang digunakan yaitu proportioned random sampling.

Instrumen dalam penelitian ini meliputi skala prokrastinasi akademik, skala sense of community, dan skala self regulated learning. Skala prokrastinasi akademik disusun berdasarkan skala yang dikembangkan oleh Pratiwi (Pratiwi, 2017). Daya diskriminasi item berkisar antara 0,301 - 0,673 dan koefisien reliabilitas skala sebesar 0,712, maka dapat disimpulkan bahwa skala tersebut memiliki reliabilitas yang tinggi.

Pengukuran Sense of Community diperoleh melalui skala Sense of Community yang disusun dari aspek-aspek sense of community yang dikemukakan oleh McMillan dan Chavis (Maryam, 2017). Hasil analisis item menunjukkan bahwa semua aitem yang berjumlah 24 aitem adalah dapat dipakai dengan pergerakan daya diskriminasi aitem sebesar 0.331 - 0.723 dan koefisien reliabilitas dengan menggunakan teknik konsistensi internal yang berupa alpha cronbach sebesar 0.927 .

Pengumpulan data Self-Regulated Learning diperoleh melalui skala Self-Regulated Learning yang disusun oelh peneliti dari aspek-aspek Self-Regulated Learning yang meliputi: Self evaluation, goal setting and planning, seeking information, keeing record and monitoring, slef-consequence, seeking social assistance, reviewing record, environmental structuring (Zimmerman \& Martinez-Pons, 1988; Mulyadi et al., 2016). Jumlah yang memiliki daya diskriminasi agus dari skala SRL sebanyak 45 item dari 56 item yang dianalisa, dengan pergerakan daya diskriminasi aitem

188 | Journal An-nafs: Vol. 4 No. 2 Desember 2019 
Effy Wardati M, Ghozali Rusyid A \& Vanda Rezania | Sense of

bergerak dari 0.300 - 0.662 dan reliabiilitas yang menggunakan konsitensi internal (teknik alpha cronbach) sebesar 0.933.

Analisis data dalam penelitian ini menggunakan analisis regresi ganda untuk mengetahui hubungan dan daya prediksi variabel bebas (SoC dan SRL) terhadap variabel tergatung yaitu Prokrastinasi Akademik, dengan bantuan SPSS 18 untuk proses analisis.

\section{Paparan Hasil}

Berdasarkan analisis deskriptif untuk mengetahui sebaran nilai ketiga variabel pada Mahasiswa Universitas Muhammadiyah Sidoarjo, diperoleh hasil sebagai berikut.

Tabel 1. Deskripsi SoC, SRL dan Prokrasinasi Akademik

\begin{tabular}{|c|c|c|c|c|c|}
\hline Variabel & $\mathrm{N}$ & Mean & SD & Min & Max \\
\hline SoC & 369 & 43.7805 & 9.68319 & 14.00 & 78.00 \\
\hline SRL & 369 & 128.0298 & 14.06880 & 92.00 & 170.00 \\
\hline PA & 369 & 50.4607 & 8.24649 & 27.00 & 72.00 \\
\hline \multicolumn{6}{|c|}{ Sense Of Community (SoC); Self Regulated Learning (SRL); } \\
Prokrastinasi Akademik (PA) \\
\hline
\end{tabular}

Hasil tersebut menunjukkan bahwa skor minila SoC sebesar 14 dan skor maksimal sebesar 78, serta rata-rata SoC pada Mahasiswa Universitas Muhammadiyah Sidoarjo sebesar 43.7805 dengan standard deviasi sebesar 9.68319. Adapun skor SRL pada Mahasiswa Universitas Muhammadiyah Sidoarjo minimal 92 dan skor maksimal sebesar 170, serta rata-rata skor SRL sebesar 128.0298 dengan standard deviasi sebesar 14.06880. Sedangkan skor minimal prokrastinasi akademik Mahasiswa Universitas Muhammadiyah Sidoarjo sebesar 27 dan skor maksimal sebesar72, dimana rata-rata skor SRL sebesar 50.4607 dengan standard deviasi sebesar 8.24649.

Selanjutnya dilakukan uji korelasi untuk mengetahui seberapa kuat ketiga variabel saling berhubungan serta untuk mengetahui arah hubungan di antara ketiga varaibel. Berdasarkan 
Effy Wardati M, Ghozali Rusyid A \& Vanda Rezania | Sense of

uji korelasi antara variabel SoC, SRL dan prokrastinasi akademik pada mahasiswa Universitas Muhammadiyah Sidoarjo diperoleh hasil sebagai berikut:

Tabel 2. Korelasi antara SoC, SRL dan Prokrasinasi Akademik

\begin{tabular}{|c|c|c|c|}
\hline \multirow{2}{*}{ Variabel } & \multicolumn{3}{|c|}{ PA } \\
\cline { 2 - 4 } & Korelasi & Sig. (p) & $\mathrm{n}$ \\
\hline SoC & $-0.312^{* *}$ & 0.000 & 369 \\
\hline SRL & $-0.690^{* *}$ & 0.000 & 369 \\
\hline \multicolumn{3}{|c|}{$\begin{array}{c}\text { Sense of Community (SoC); Self Regulated Learning (SRL); } \\
\text { Prokrastinasi Akademik (PA). }{ }^{* *} \mathrm{p}<0.01 \text { (two tailed) }\end{array}$} \\
\hline
\end{tabular}

Berdasarkan tabel 2 di atas menunjukkan bahwa korelasi (rxy) antara SoC dengan prokrastinasi akademik sebesar -0.312 dengan $\mathrm{p}=0.000<0.01$, artinya terdapat hubungan negatif yang signifikan antara SoC dengan prokrastinasi akademik. Meningkatnya SoC pada mahasiswa akan diikuti penurunan prokrastinasi akademik, begitu juga sebaliknya jika SoC rendah maka akan diikuti prokrastinasi akademik yang cenderung tinggi. Adapun besar korelasi antara SRL dengan prokasinasi akademik didapatkan rxy $=-0.690$ dan $p=0.000<0.01$ yang menunjukkan bahwa SRL memiliki hubungan negatif dengan prokrastinasi akademik, dimana apabila SRL mahasiswa meningkat maka akan diikuti penurunan Prokrastinasi Akademik, begitu pula sebaliknya apabila SRL turun maka akan diikuti oleh Prokrastinasi Akademik yang cenderung naik. Apabila dibandingkan besar korelasi antara SoC dengan Prokrastinasi Akademik dan SRL dengan Prokrastinasi Akademik maka korelasi antara SRL dengan Prokrastinasi Akademik menunjukkan hubungan yang lebih kuat ( $r x y=-0.690$ ) dibandingkan hubungan antara SoC dengan Prokrastinasi Akademik ( $r x y=-0.312)$.

Berdasarkan uji regresi ganda untuk mengetahui daya prediksi, terlihat bahwa kedua variabel secara bersama-sama dapat mempengaruhi prokrastinasi akademik. Beikut ini hasil selengkapnya disajikan dalam tabel 3. 
Effy Wardati M, Ghozali Rusyid A \& Vanda Rezania | Sense of

Tabel 3. Hasil Uji Regresi Ganda SoC dan SRL terhadap Prokrasinasi Akademik (PA)

\begin{tabular}{|c|c|c|c|}
\hline Model Regresi & F hitung & Sig. & $\begin{array}{c}\text { Adjusted R } \\
\text { Square }\end{array}$ \\
\hline SoC*SRL & 166.587 & 0.000 & 0.474 \\
\hline SoC & 39.620 & 0.000 & 0.095 \\
\hline SRL & 333.720 & 0.000 & 0.475 \\
\hline
\end{tabular}

C*SSRL , Model secara bersama-sama Sense Of Community (SoC) dan Self Regulated Learning (SRL); Sense Of Community (SoC); Self Regulated Learning (SRL); Dependent variabel, Prokrasinasi Akademik (PA).

Hasil analisis pada tabel 3 di atas menunjukkan bahwa secara bersama-sama sense of community dan self-regulated learning dapat mempengaruhi prokrastinasi akademik secara signifikan, dimana F Hitung $=166.587$ dan $\mathrm{p}=0.000<0.01$, serta memiliki daya prediksi sebesar $47.4 \%$ (Adjusted R Square $=0.474$ ). Jika dilihat secara sendiri-sendiri masing-masing variabel bebas yaitu sense of community dan self-regulated learning memiliki pengaruh terhadap prokrastinasi akademik dengan $\mathrm{F}$ hitung untuk sense of community terhadap prokrastinasi akademik $=39.620$ dan $\mathrm{p}=0.000<0.01$ dan self-regulated learning terhadap prokrastinasi akademik $\mathrm{F}=333.720$ dan $\mathrm{p}=0.000<0.01$. Namun jika dibandingkan daya prediksi antara SoC dengan SRL terhadap Prokrastinasi Akademik terlihat bahwa daya prediksi SRL terhadap Prokrastinasi akademik lebih tinggi yaitu sebesar 47.5\% sedangkan daya prediksi SoC terhadap Prokrastinasi Akademik hanya sebesar 9.5\%. Hal ini menunjukkan bahwa SRL memiliki pengaruh yang lebih kuat terhadap prokrastinasi akademik dibandingkan pengaruh SoC terhadap Prokrastinasi Akademik.

\section{Pembahasan}

Berdasarkan analisis yang dilakukan diperoleh hasil bahwa terdapat hubungan antara sense of community (SoC) dan selfregulated learning (SRL) dengan prokrastinasi akademik pada mahasiswa Universitas Muhammadiyah Sidoarjo. Hal ini 
Effy Wardati M, Ghozali Rusyid A \& Vanda Rezania | Sense of

menunjukkan bahwa sense of community dan self-regulated learning menjadi faktor yang berpengaruh terhadap prokrastinasi akademik.

SoC merupakan sebuah perasaan dimana seseorang merasa memiliki dan memaknai sebagai bagian dari kebersamaan yang besar pada kelompok meskipun terjadi berbagai konflik namun dapat teratasi dengan baik oleh anggota kelompok, serta perasaan dimana ada jaringan dan struktur hubungan yang menguatkan dari perasaan kesepian (loneliness) yang akan memberikan jarak. McMillan dan Chavis (dalam Prayoga \& Herdiyanto, 2014), mengatakan bahwa sense of community merupakan perasaan memiliki terhadap sebuah komunitas dan perasaan berharga dalam suatu komunitas, sehingga timbul keyakinan untuk bersama-sama dalam komunitas. Berdasarkan definisi tersebut, unsur-unsur yang paling penting dari komunitas meliputi saling ketergantungan timbal balik di antara anggota, rasa memiliki, keterhubungan, semangat, kepercayaan, interaktivitas, harapan bersama, nilai-nilai dan tujuan bersama, serta kesamaan latar belakang di antara anggota komunitas.

Prokrastinasi akademik mengacu pada penundaan secara sengaja dari kegiatan yang diinginkan meskipun individu mengetahui bahwa perilaku penundaan tersebut menghasilkan dampak buruk (Goroshit, 2018). Seseorang yang memiliki sense of community yang tinggi akan mendorong individu bekerja dengan lebih baik. Mahasiswa yang memiliki sense of community tinggi merasa nyaman saat menjalin relasi dengan kelompoknya, hal ini dapat menjadikan kerjasama antar anggota kelompok dapat terjalin sehingga tugas-tugas akademik lebih mudah untuk diselesaikan (Rovai, 2002).

Liu menjelaskan bahwa terdapat korelasi positif antara sense of community yang lebih tinggi dengan keterlibatan pembelajaran yang dirasakan mahasiswa, belajar, rasa memiliki (sense of belonging), dan kepuasan mahasiswa (Beeson et al., 2019). Kepuasan tersebut bisa diperoleh dari adanya kepercayaan yang tinggi di antara mahasiswa untuk saling memberikan bantuan,

192 | Journal An-nafs: Vol. 4 No. 2 Desember 2019 
terutama dalam menghadapi tugas perkuliahan yang dirasakan sulit. Selain itu, menurut Drouin, sense of community berkorelasi terhadap interaksi antar mahasiswa dan interaksi antar mahasiswa dengan pihak fakultas maupun universitas (Beeson et al., 2020). Chow menyatakan bahwa mahasiswa yang kepuasannya rendah dalam proses pembelajaran di kampus, cenderung melakukan prokrastinasi akademik. Hal ini berkaitan dengan motivasi dan ketertarikan yang rendah terhadap pihak program studi atau universitas (Purwantika et al., 2013).

Mahasiswa yang memiliki tingkat sense of community yang lebih tinggi, juga berkaitan dengan penurunan kesepian dan stres dalam program pembelajaran (Elkins, Forrester, \& Noel-Elkins, 2011). Hal ini sejalan dengan hasil penelitian Prati dkk yang menunjukkan bahwa sense of community pada mahasiswa berkaitan dengan kesejahteraan (well-being), dimana mahasiswa akan memiliki perasaan dan fungsi positif dalam menjalani berbagai kegiatan di kampus, termasuk mengerjakan berbagai tugas perkuliahan (Prati, Cicognani, \& Albanesi, 2018). Sense of community yang rendah akan menyebabkan ketidakpuasan mahasiswa dan kesejahteraan yang rendah, sehingga memungkinkan melakukan prokrastinasi akademik.

Hasil penelitian menunjukkan bahwa terdapat hubungan antara Self Reguated Learning dengan prokrastinasi akademik dengan besar korelasi sebesar $-0.690^{* *}$ dan Sig. $0.000<0.01$. hal ini memperkuat hasil penelitian sebelumnya yang menunjukkan bahwa flow dan Self Reguated Learning merupakan faktor yang signifikan dalam memprediksi prokrastinasi aktif (Kim \& Seo, 2013). Penelitian lain juga menemukan bahwa disorganisasi dan kemampuan yang lemah dalam menggunakan metakognitif saat belajar memiliki hubungan yang positif dengan prokrastinasi (Howell \& Watson, 2007).

Begitu juga apabila mahasiswa memiliki usaha untuk melakukan regulasi yang rendah, kemampuan regulasi diri yang rendah serta memiliki motivasi intrinsik yang rendah dalam belajar secara online akan meningkatkan prokrastinasinya (Rakes \& Dunn, 
n.d.). Dimana dalam penelitian ersebut didapatkan korelasi yang negatif antara motivasi instrinsik dan regulasi diri dengan prokrastinasi (-0.36 dan -0.38) hal ini menunjukkan bahwa motivasi instrinsik untuk belajar dan regulasi diri dalam belajar menurun maka prokrastinasi akan meningkat (Rakes \& Dunn, n.d.). Hal ini disebabkan karena apabila orientasi tujuan instrinsik rendah, reguasi diri dalam hal metakognitif cenderung rendah serta menejemen waktu belajar rendah maka seorang mahasiswa akan cenderung melakukan prokrastinasi (Motie, Heidari, \& Alsadat, 2012).

Menurut Motie et al.(2012) bahwa siswa yang memiliki evaluasi internal tinggi yang merupakan bagian dari aspek regulasi diri jarang melakukan prokrastinasi. Hal ini dikarenakan mahasiswa dengan regulasi diri yang baik saat belajar yang dilakukan pertama kali adalah melakukan evaluasi serta perencanaan strategi belajar. Selain itu, mahasiswa yang memiliki regulasi diri yang baik ternyata memiliki strategi untuk mencapai sebuah target yang telah disusun sebelumnya (Wolters, 2003).

Menurut San, Roslan, \& Sabouripour (2016) bahwa keterkaitan antara regulasi diri pada komponen motivasi dan komponen strategi belajar dengan prokrastinasi akademik sejalan dengan Temporal Motivation Theory (TMT) dimana sebagian besar komponen self regulted learning berkaitan dengan prokrastinasi akademik. Berdasarkan hal tersebut, menjadi pembelajar yang memiliki kemampuan regulasi diri akademik yang baik, seperti memiliki orientasi tujuan instrinsik dan ekstrinsik yang jelas, keyakinan mampu mengontrol belajar, efikasi diri dalam belajar, pengorganisian dalam belajar, metakognisi serta kemampuan mengevaluasi diri akan menjadikan mahasiswa mampu untuk mengurangi prokrastinasi akademiknya (San et al., 2016). Oleh sebab itu, mahasiswa seharusnya tidak hanya belajar mengenai konten materi perkuliahan, namun juga belajar bagaimana belajar yang bagus sesuai konsep regulasi diri akademik agar kesulitankesulitan yang dihadapi saat melakukan proses belajar di 
perguruan tinggi yang menuntut kemandirian dapat dilakukan secara maksimal.

Lebih jauh Motie et al. (2012) menjelaskan bahwa strategi metakognisi merupakan prediktor pada prokrastinasi akademik. Strategi metakognisi ini berkenaan dengan kemampuan evaluasi diri, mengontrol dirinya serta bertanya kepada dirinya (Motie et al., 2012). Dimana mahasiswa yang memiliki kemampuan metakognisi serta dapat mengontrol kondisi belajar lebih mampu untuk memprediksi hambatan sekaligus mencari solusi dari hambatan saat mengerjakan tugas-tugas belajarnya.

Penelitian ini juga menemukan bahwa besar prediksi Self Regulated Learning lebih tinggi dari pada Sense of Community terhadap prokrastinasi akademik. Kedua variabel bebas tersebut merupakan faktor prokrastinasi yang berkenaan dengan faktor intrinsik dan ekstrinsik. Ada 2 bentuk prokrastinasi yang berkenaan dengan faktor intrinsik dan ekstrinsik yaitu prokrastinasi aktif dan pasif yang berkenaan dengan. Prokratinasi aktif mengarah pada pembuatan keputusan yang disengaja untuk menunda-nunda, sehingga memiliki motivasi yang kuat meskipun dibawah tekanan waktu, mereka dapat menyelesaikan tugas sebelum tengang waktu habis serta dapat mencapai hasil yang memuaskan. Berbeda dengan prokrastinasi pasif yang merupakan prokrastinasi dalam bentuk penunadaan sampai batas akhir disertai dengan perasaan bersalah dan tertekan serta cenderung agagal menyelesaikan tugas (Choi \& Moran, 2009). Prokrastnasi aktif dan pasif memiliki perbedaan pada level kemampuan meregulasi diri, termasuk didalamnya elaborasi, pengroganisasian, pemikiran kritis, nilai tugas, kecemasan, managemen waktu dan usaha untuk melakukan kontrol (Shin \& Goh, 2011).

Mahasiswa yang memiliki motivasi ekstrinsik dan nonautonomous akan cenerung melakukan prokrastinasi pasif dari pada prokrastinasi aktif. Selain itu, regulasi yang disebabkan tuntutan eksternal, seperti mengerjakan tugas karena takut sangsi dari orang tua atau dosen, motivasi karena teman satu kelompok akan meningkatkan prokrastinasi pasif dan menurunkan 
Effy Wardati M, Ghozali Rusyid A \& Vanda Rezania | Sense of

menurunkan prokrastinasi aktif (Seo, 2013), apabila tidak dimbangi oleh tingginya aspek dari regulasi diri akademik seperti kemampuan metakognitif. Berbeda dengan siswa yang dapat melakukan regulasi intrinsik (regulasi diri) cenderung dapat menyelesaikan tugas dengan tepat waktu dan lebih bagus dan melakukan prokrastinasi aktif. Namun, faktor ekstrinsik tetap mempengaruhi prokrastinasi akademik sebagaimana penelitian dari Rosário et al. (2009) dimana prokrastinasi cenderung turun ketika pendidikan orang tua (ayah dan Ibu) meningkat, tetapi prokrastinasi akan naik apabila peringkat sekolah yang semakin turun, dan tergolong siswa yang memiliki prestasi rendah. Penelitian ini mengandung kelemahan bahwa analisa secara lebih detail mengenai aspek-aspek Sense of Community dan Self Regulated Learning terhadap prokrastinasi akademik tidak dibahas. Selain itu, membedakan mahasiswa yang tidak bekerja dan bekerja, dalam kaitannya dengan prokrastinasi akademik yang ditinjau dari Sense of Community dan Self Regulated Learning belum menjadi focus kajian serta membedakan prokrastinasi aktif dan pasif dari susut pandang kedua variabel masih perlu dikaji ulang.

\section{Simpulan}

Penelitian ini menemukan bahwa terdapat hubungan negatif antara sense of community dan self regulated learning. Apabila sense of community dan self regulated learning rendah maka akan berdampak pada meningkatnya prokrastinasi akademik mahasiswa UMSIDA, begitu juga apabila sense of community dan self regulated learning tinggi maka prokrastinasi akademik mahasiswa UMSIDA menurun. Selain itu, ditemukan bahwa secara bersama-sama sense of community dan self regulated learning mempengaruhi prokrastinasi akademik, namun daya prediksi self regulated learning lebih tinggi dari pada sense of community terhadap prokrastinasi akademik siswa.

196 | Journal An-nafs: Vol. 4 No. 2 Desember 2019 
Effy Wardati M, Ghozali Rusyid A \& Vanda Rezania | Sense of

\section{Saran}

Bagi penelitian selanjutnya, peneliti perlu mengkaji secara lebih detil tentang keterkaitan aspek-aspek sense of community dan self regulated learning pada prokrastinasi aktif dan pasif, serta melihat aspek demografis mahasiswa seperti mahasiswa tidak bekerja dan mahasiswa bekerja terhadap prokrastinasi akademik, jenis kelamin, fakultas, dan lain-lain. Selain itu, bisa meneliti tentang model prokrastinasi akademik dari sudut pandang faktor eksternal dan internal dimana sense of community sebagai moderator hubungan antaras self-regulated learning dengan prokrastinasi akademik serta bentuk sense of community.

Bagi mahasiswa, perlu meningkatkan sense of community yang bersandar pada komunitas mahasiswa yang berprestasi untuk menurunkan prokrastinasi akademik. Mahasiswa juga perlu mengembangkan metode belajar yang berpedoman pada selfregulated learning.

Bagi pihak universitas, hasil penelitian ini bisa digunakan sebagai acuan untuk membuat pelatihan Self-Regulated Learning sebagai upaya untuk menurunkan angka prokrastinasi akademik pada mahasiswa. 
Effy Wardati M, Ghozali Rusyid A \& Vanda Rezania | Sense of

\section{Daftar Pustaka}

Beeson, E., Aideyan, B., Shoney, C. O., Bowes, D. A., Ansell, K. L., \& Peterson, H. M. (2020). Predicting Sense of Community among Graduate Students in a Distance Learning Environment, 7(3), 746-753. https://doi.org/10.13189/ujer.2019.070314

Choi, J. N., \& Moran, S. V. (2009). Why not procrastinate? Development and validation of a new active procrastination scale. The Journal of Social Psychology, 149(2), 195-211.

Dalton, J. H., Elias, M. J., \& Wandersman, A. (2007). Community Psychology: Lingking Individuals and Communities. California: Thomson Wadsworth.

de Palo, V., Monacis, L., Miceli, S., Sinatra, M., \& Di Nuovo, S. (2017). Decisional procrastination in academic settings: The role of metacognitions and learning strategies. Frontiers in Psychology, 8(June), 1-8. https://doi.org/10.3389/fpsyg.2017.00973

Garcia, D., Jimmefors, A., Mousavi, F., Adrianson, L., Rosenberg, P., \& Archer, T. (2015). Self-regulatory mode (locomotion and assessment), well-being (subjective and psychological), and exercise behavior (frequency and intensity) in relation to high school pupils' academic achievement. PeerJ, 3, e847. https://doi.org/10.7717/peerj.847

Ghufron, M. N., \& Risnawita, R. (2016). Teori-teori Psikologi. Yogyakarta: Ar-Ruzz.

Goroshit, M. (2018). Academic procrastination and academic performance: An initial basis for intervention. Journal of Prevention and Intervention in the Community, 46(2), 131142. https://doi.org/10.1080/10852352.2016.1198157

Howell, A. J., \& Watson, D. C. (2007). Procrastination : Associations with achievement goal orientation and learning strategies. Personality and Individual Differences, 43, 167-178. https://doi.org/10.1016/j.paid.2006.11.017

Kim, E., \& Seo, E. H. (2013). The relationship of flow and selfregulated learning to active procrastination. Social Behavior And Personality, 41(7), 1099-1114. https://doi.org/http://dx.doi.org/10.2224/sbp.2013.41.7.10 99

Maryam, E. W. (2017). Gambaran Sense Of Community Pada Karyawan Bagian Administrasi Di Universitas Muhammadiyah Sidoarjo, 2(January), 52-64.

198 | Journal An-nafs: Vol. 4 No. 2 Desember 2019 
Effy Wardati M, Ghozali Rusyid A \& Vanda Rezania | Sense of

Motie, H., Heidari, M., \& Alsadat, M. (2012). Predicting academic procrastination during self-regulated learning in iranian first grade high school students. Procedia - Social and Behavioral Sciences, 69(Iceepsy 2012), 2299-2308. https://doi.org/10.1016/j.sbspro.2013.02.023

Mulyadi, S., Basuki, A. M. H., \& Rahardjo, W. (2016). Psikologi Pendidikan: dengan Pendekatan Teori-teori Baru Dalam Psikologi. Jakarta: Rajawali Pers.

Mulyadi, S., Basuki, H., \& Rahardjo, W. (2017). Psikologi Pendidikan: Dengan Pendekatan Teori-teori Baru dalam Psikologi (1st ed). Depok: Rajawali Pers.

Onwuegbuzie, A. (2004). Academic procrastination and statistics anxiety. Assessment and Evaluation in Higher Education, 29(1), 3-19.

Ormrod, J. E. (2008). Psikologi Pendidikan: Membantu Siswa Tumbuh dan Berkembang. Jakarta: Erlangga.

Panadero, E. (2017). A review of self-regulated learning: Six models and four directions for research. Frontiers in Psychology, 8(APR), 1-28. https://doi.org/10.3389/fpsyg.2017.00422

Prati, G., Cicognani, E., \& Albanesi, C. (2018). The influence of school sense of community on students' well-being: A multilevel analysis. Community Psychology, 46(7), 917-924.

Pratiwi, D. C. (2017). Prokrastinasi Akademik Pada Mahasiswa Universitas Muhammadiyah Sidoarjo. Universitas Muhammadiyah Sidoarjo.

Purwantika, W., Setyawan, I., \& Ariati, J. (2013). Hubungan Antara Sense of Community Dengan Prokrastinasi Akademik Pada Mahasiswa Fakultas Psikologi Universitas Diponegoro Semarang. Empati.

Rakes, G. C., \& Dunn, K. E. (n.d.). The Impact of Online Graduate Students ' Motivation and Self- Regulation on Academic Procrastination, (1998), 78-93.

Rosário, P., Costa, M., Núñez, J. C., González-pienda, J., Solano, P., \& Valle, A. (2009). Academic procrastination : Associations with personal , school , and family variables. The Spanish Journal of Psychology, 12(1), 118-127.

Rovai, A. P. (2002). Building Sense of Community at a Distance School of Education. Psychological Science, 6, 45-48.

San, Y. L., Roslan, S. B., \& Sabouripour, F. (2016). Relationship between self-regulated learning and academic procrastination. American Journal of Applied Sciences, 13(4), 
Effy Wardati M, Ghozali Rusyid A \& Vanda Rezania | Sense of

459-466. https://doi.org/10.3844/ajassp.2016.459.466

Seo, E. H. (2013). A comparison of active and passive procrastination in relation to academic motivation. Social Behavior And Personality, 41(5), 777-786. https://doi.org/http://dx.doi.org/10.2224/sbp.2013.41.5.77 $7 \mathrm{~A}$

Shin, E. J., \& Goh, J. K. (2011). The relations between active-passive procrastination behavior and self-regulated learning strategies. Korean Journal of Educational Science, 42, 25-47.

Steel, P. (2007). The Nature of Procrastination : A Meta Analytic and Theoretical Review of Quintessential Self-Regulatory Failure. Psychological Bulletin of American Psychological Association, 133, 65-94.

Sugiyono. (2011). Metode Penelitian Kuantitatif, Kualitatif, dan $R \& D$. Bandung: Alfabeta.

Wolters, C. A. (2003). Understanding procrastination from a selfregulated learning perspective. Journal of educational psychology, 95(1), 179., 95(1), 179.

Zimmerman, B. J., \& Martinez-Pons, M. (1988). Construct Validation of a Strategy Model of Student Self-Regulated Learning. Journal of Educational Psychology, 80(3), 284-290. https://doi.org/10.1037/0022-0663.80.3.284 